\title{
Epitaxial Growth of Calcite Crystals on Dolomite and Kutnahorite (104) Surfaces
}

\author{
Carlos Pimentel, ${ }^{\dagger \neq}$ Carlos M. Pina, ${ }^{*}, \dagger \neq$ and Enrico Gnecco ${ }^{\S}$ \\ ${ }^{\dagger}$ Departamento de Cristalografía y Mineralogía, Universidad Complutense de Madrid, E-28040 Madrid, Spain \\ ${ }^{\ddagger}$ Instituto de Geociencias (UCM-CSIC), C/José Antonio Novais, 2, E-28040 Madrid, Spain \\ ${ }^{\S}$ Instituto Madrileño de Estudios Avanzados en Nanociencia, IMDEA Nanociencia, Campus Universitario de Cantoblanco, E-28049 \\ Madrid, Spain
}

\begin{abstract}
Epitaxial growth of calcite on dolomite and kutnahorite (104) surfaces has been promoted at room temperature by immersing cleavage rhombohedra of these minerals in highly supersaturated solutions with respect to calcite $\left(\beta_{\text {calcite }}=\left[\mathrm{a}\left(\mathrm{Ca}^{2+}\right) \cdot \mathrm{a}\left(\mathrm{CO}_{3}{ }^{2-}\right) / \mathrm{K}_{\mathrm{sp} \text {,calcite }}\right]>20\right)$. Scanning electron microscopy (SEM) images revealed an inhomogeneous coverage of dolomite and kutnahorite surfaces by large calcite crystals. In situ atomic force microscopy (AFM) observations showed that, while calcite islands rapidly grow perpendicularly to the substrates, their lateral spreading is slower. Furthermore, the accumulated strain associated with the relatively high calcite -substrate lattice misfits $(\delta>2.2 \%)$ is accommodated by the generation of screw dislocations, which are evidenced by growth spirals on calcite three-dimensional islands. These observations are consistent with the Volmer-Weber epitaxial growth mode, characteristic of high overgrowth -substrate lattice misfits. Additional nanomanipulation experiments conducted with the AFM tip allowed us to remove calcite islands on both dolomite and kutnahorite (104) surfaces and to provide first estimates of shear strength.
\end{abstract}

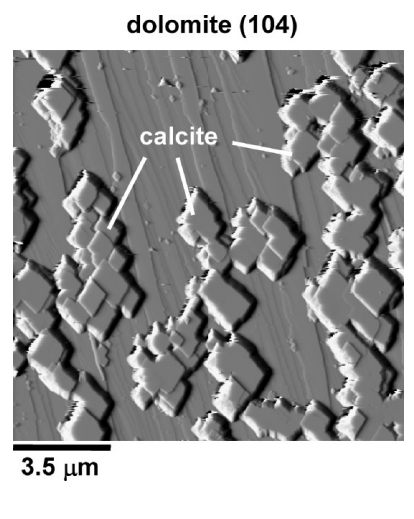

\section{INTRODUCTION}

Despite the numerous investigations conducted in recent decades, the anomalous reactivity of the mineral dolomite, $\mathrm{MgCa}\left(\mathrm{CO}_{3}\right)_{2}$, in aqueous environments still constitutes an intriguing mineralogical problem. $^{1,2}$ In the upper Earth's Crust, dolomite is, after calcite, the most abundant rock-forming carbonate mineral. However, dolomite is a very rare mineral in quaternary sediments when compared with its massive formation in analogous ancient sedimentary environments. Only in very restricted present environments, such as some sabkhas, lagoons, and tidal zones, the precipitation of dolomite has been reported. ${ }^{3}$ Moreover, under controlled laboratory conditions it has been found that direct dolomite precipitation only occurs at temperatures above $100{ }^{\circ} \mathrm{C}$, in disagreement with geological evidence. ${ }^{3}$ But not only is the crystallization of dolomite in nature difficult to explain. The thermodynamics and kinetics of the reverse reaction, i.e., dissolution, are poorly understood too. Indeed, the reported values of the solubility product for dolomite at $25{ }^{\circ} \mathrm{C}$ vary in about 3 orders of magnitude. ${ }^{4}$ In addition, dissolution rates for ordered dolomite are difficult to predict. ${ }^{4,5}$

Interestingly, the anomalous reactivity of dolomite is not exclusive of this mineral, but also affects other minerals of its group. For instance, kutnahorite, the so-called manganese dolomite, $\mathrm{MnCa}\left(\mathrm{CO}_{3}\right)_{2}$, shows a complex dissolution behavior involving the secondary metastable formation of disordered $\mathrm{Mn}$ - Ca phases, which makes the determination of its solubility product troublesome. ${ }^{6}$ On the other hand, recent precipitation experiments and calorimetric measurements clearly indicate that the precipitation of ordered kutnahorite is kinetically inhibited in favor of disordered $\mathrm{Mn}-\mathrm{Ca}$ carbonates. ${ }^{7}$ Furthermore, some synthetic compounds with dolomite structure (e.g., the so-called $\mathrm{Cd}$-dolomites) have been only crystallized at temperatures above $300{ }^{\circ} \mathrm{C}$, while attempts to synthesize other transition metal dolomites (e.g., $\left.\mathrm{CoCa}\left(\mathrm{CO}_{3}\right)_{2}, \mathrm{NiCa}\left(\mathrm{CO}_{3}\right)_{2}\right)$ were not successful. ${ }^{8}$

Since mineral reactions mainly take place at the mineral surfaces, a number of recent investigations on the anomalous reactivity of the dolomite group of minerals have been reasonably focused on the nanoscale phenomena occurring on dolomite and calcite surfaces. Most of these investigations have been addressed to grow crystal monolayers with cationic ordering in structural continuity with dolomite and calcite (104) faces. Although this objective has not been achieved to date, different researchers have succeeded in growing a few epitaxial layers on both calcite and dolomite surfaces from supersaturated aqueous solutions at room temperature. ${ }^{5,9}$

At relatively high supersaturations with respect to ordered dolomite, the growth of two continuous monolayers on the dolomite (104) face has been observed by atomic force microscopy (AFM). ${ }^{5}$ The way in which this growth proceeds resembles the so-called Frank-Van der Merwe layer-by-layer epitaxial growth mode. ${ }^{10}$ However, growth stops once the first two monolayers are formed, further multilayer growth being 
Table 1. Conditions and Results of the Crystallization Experiments

\begin{tabular}{|c|c|c|c|c|c|c|c|c|c|}
\hline \multirow[b]{2}{*}{ expt } & \multirow[b]{2}{*}{$\mathrm{Na}_{2} \mathrm{CO}_{3}(\mathrm{mmol} / \mathrm{L})$} & \multirow[b]{2}{*}{$\mathrm{CaCl}_{2}(\mathrm{mmol} / \mathrm{L})$} & \multirow[b]{2}{*}{$a\left(\mathrm{CO}_{3}{ }^{2-}\right)\left(\times 10^{-4}\right)$} & \multirow[b]{2}{*}{$a\left(\mathrm{Ca}^{2+}\right)\left(\times 10^{-4}\right)$} & \multicolumn{2}{|c|}{$\mathrm{pH}$} & \multirow[b]{2}{*}{$\beta_{\text {calcite }}$} & \multirow[b]{2}{*}{ substrate } & \multirow[b]{2}{*}{ epitaxial growth } \\
\hline & & & & & calcd & measd & & & \\
\hline C-1D & 0.72 & 0.72 & 2.37 & 4.27 & 10.35 & 10.37 & 30 & dolomite & no \\
\hline $\mathrm{C}-2 \mathrm{D}$ & 0.78 & 0.78 & 2.55 & 4.52 & 10.37 & 10.41 & 35 & dolomite & no \\
\hline C-3D & 0.85 & 0.85 & 2.75 & 4.79 & 10.38 & 10.38 & 40 & dolomite & scarce \\
\hline$C-4 \mathrm{D}$ & 0.94 & 0.94 & 3.01 & 5.13 & 10.40 & 10.43 & 45 & dolomite & clear \\
\hline C-5D & 1.00 & 1.00 & 3.17 & 5.35 & 10.41 & 10.46 & 50 & dolomite & clear \\
\hline$C-6 D$ & 1.05 & 1.05 & 3.31 & 5.53 & 10.42 & 10.45 & 55 & dolomite & clear \\
\hline $\mathrm{C}-1 \mathrm{~K}$ & 0.27 & 0.27 & 8.47 & 2.04 & 10.13 & 10.12 & 5 & kutnahorite & no \\
\hline $\mathrm{C}-2 \mathrm{~K}$ & 0.40 & 0.40 & 1.32 & 2.78 & 10.22 & 10.24 & 10 & kutnahorite & no \\
\hline $\mathrm{C}-3 \mathrm{~K}$ & 0.50 & 0.50 & 1.66 & 3.29 & 10.27 & 10.30 & 15 & kutnahorite & no \\
\hline $\mathrm{C}-4 \mathrm{~K}$ & 0.57 & 0.57 & 1.89 & 3.62 & 10.30 & 10.30 & 20 & kutnahorite & scarce \\
\hline C-5K & 0.64 & 0.64 & 2.12 & 3.93 & 10.33 & 10.37 & 25 & kutnahorite & scarce \\
\hline C-6K & 0.72 & 0.72 & 2.37 & 4.27 & 10.35 & 10.37 & 30 & kutnahorite & clear \\
\hline $\mathrm{C}-7 \mathrm{~K}$ & 0.78 & 0.78 & 2.55 & 4.52 & 10.37 & 10.35 & 35 & kutnahorite & clear \\
\hline $\mathrm{C}-8 \mathrm{~K}$ & 0.85 & 0.85 & 2.75 & 4.79 & 10.38 & 10.34 & 40 & kutnahorite & clear \\
\hline C-9K & 0.94 & 0.94 & 3.01 & 5.13 & 10.40 & 10.34 & 45 & kutnahorite & clear \\
\hline C-10K & 1.00 & 1.00 & 3.17 & 5.35 & 10.41 & 10.42 & 50 & kutnahorite & clear \\
\hline
\end{tabular}

strongly inhibited. A first characterization of the monolayers grown on dolomite (104) faces by measuring friction forces with AFM indicates that their structure and/or composition varies with the aqueous $\mathrm{Ca}^{2+} / \mathrm{Mg}^{2+}$ ratio. ${ }^{9}$ In addition, an estimate of the surface energy from dissolution at different saturation states showed that the monolayers on dolomite have an excess of interfacial strain energy. ${ }^{9}$ Experiments similar to those conducted by Higgins and $\mathrm{Hu}^{9}$ but using calcite (104) faces as substrates resulted in a more complex growth behavior. ${ }^{1-14}$ At moderate supersaturated solutions with respect to both dolomite and Mg-calcites, and low magnesium contents, continuous layer-by-layer growth mechanism was reported. Nevertheless, $\mathrm{Mg}^{2+}$ has a clear inhibiting effect and it reduces steps rates as its concentration increases in the growth solutions. At highly supersaturated solutions with respect to dolomite, Sethmann et al. ${ }^{14}$ observed by AFM that the epitaxial growth according to the Frank-Van der Merwe layer-by-layer mode only occurs on calcite (104) surfaces until about 40 monolayers are formed (i.e., a layer of $120 \mathrm{~nm}$ in thickness). Then, the development of straight ridges was observed and further growth resulted in a segmentation of the crystal surface and the subsequent formation of a micromosaic-like structure. Molecular dynamics computational modeling suggests that the development of this surface nanostructure is due to the progressive accommodation of the strain energy associated with the mismatch between the pure calcite substrate and the magnesium containing overlayers. ${ }^{14}$ Therefore, the layer-by-layer growth until a critical thickness is reached, followed by the formation of three-dimensional islands with higher surface area, can be interpreted as the operation of the Stranski-Krastanov epitaxial growth mechanism ${ }^{15}$ on calcite surfaces.

Calcite (104) face has been also used as a substrate for promoting the growth of $\mathrm{Mn}-\mathrm{Ca}$ carbonates from aqueous solutions. In situ AFM observations showed that, for solutions with concentrations of $\mathrm{Mn}$ of a few $\mu \mathrm{M}$ and moderately supersaturated with respect to Mn-calcites, layer-by-layer growth occurs. ${ }^{16}$ Similarly to the cases of formation of layers of $\mathrm{Mg}-\mathrm{Ca}$ carbonate on both calcite and dolomite (104) faces, the growth velocity rapidly decreases with the thickness of the overgrowth and for concentrations of $\mathrm{Mn}^{2+}$ of about $50 \mu \mathrm{M}$ step rate is almost zero after the formation of the first two monolayers. However, this growth inhibition can be overcome by increasing supersaturation at the calcite-solution interface. This has been done by Lea et al., ${ }^{17}$ who allowed the (104) surface of a calcite crystal to slightly dissolve in a carbonate solution before injecting an aqueous solution containing $\mathrm{Mn}^{2+}$ in the AFM growth cell. Then the rapid formation of rodlike three-dimensional islands with a width of 120-240 nm and a height of approximately $2.7 \mathrm{~nm}$ was observed. The nucleation and spreading of these three-dimensional islands is consistent with the so-called Volmer -Weber epitaxial growth mecha-nism. ${ }^{18}$ Moreover, the shape and thickness can be explained on the basis of both elastic constants and lattice misfits between the calcite substrate and the overgrown islands.

The investigations summarized above clearly indicate that the epitaxial growth mechanism of double carbonates on dolomite and calcite (104) surfaces strongly depends on the adhesion between the substrates and the growth layers, which are mainly determined by lattice misfits. However, research conducted up to now is still insufficient to propose an integrated model for describing epitaxial growth of simple and double trigonal carbonates. Therefore, further systematic experimental work is required on this topic.

In this paper we present a new study of the epitaxial growth of pure calcite on dolomite and kutnahorite (104) surfaces from aqueous solutions. The aim of the study is to describe the operating epitaxial growth mechanism, to define the supersaturation conditions under which it occurs, and to provide information about the overgrowth-substrate adhesion. The discussion of the results will contribute to a better under-standing of the reactivity of surfaces of minerals with dolomite structure.

\section{MATERIALS AND METHODS}

2.1. Characterization of Dolomite and Kutnahorite Samples. The samples used in this work were dolomite from Eugui, Navarra (Spain), and kutnahorite from Franklin mines, New Jersey (USA). Samples were confirmed to be dolomite (PDF number 75-1710) and kutnahorite (PDF number 80-2197) by X-ray powder diffraction conducted with a Siemens D-500 diffractometer and a Philips X'Pert PRO diffractometers, both equipped with $\mathrm{Cu}$ Ka radiation sources. Dolomite diffractograms clearly show some superstructure reflections (hOl, with I odd), characteristic of cationic ordering (i.e., 101, 015, 021, and 009). ${ }^{3}$ In contrast, superstructure reflections are absent in kutnahorite diffractograms. This indicates a low degree of ordering of 
Table 2. Conditions and Results of the Experiments Conducted in the Fluid Cell of the AFM

\begin{tabular}{|c|c|c|c|c|c|c|c|c|c|}
\hline \multirow[b]{2}{*}{ expt } & \multirow[b]{2}{*}{$\mathrm{Na}_{2} \mathrm{CO}_{3}(\mathrm{mmol} / \mathrm{L})$} & \multirow[b]{2}{*}{$\mathrm{CaCl}_{2}(\mathrm{mmol} / \mathrm{L})$} & \multirow[b]{2}{*}{$a\left(\mathrm{CO}_{3}{ }^{2-}\right)\left(\times 10^{-4}\right)$} & \multirow[b]{2}{*}{$a\left(\mathrm{Ca}^{2+}\right)\left(\times 10^{-4}\right)$} & \multicolumn{2}{|c|}{$\mathrm{pH}$} & \multirow[b]{2}{*}{$\beta_{\text {calcite }}$} & \multirow[b]{2}{*}{ substrate } & \multirow[b]{2}{*}{ epitaxial growth } \\
\hline & & & & & calcd & measd & & & \\
\hline AFM-1D & 0.57 & 0.57 & 1.89 & 3.62 & 10.30 & 10.34 & 20 & dolomite & no \\
\hline AFM-2D & 0.64 & 0.64 & 2.12 & 3.93 & 10.33 & 10.31 & 25 & dolomite & no \\
\hline AFM-3D & 0.72 & 0.72 & 2.37 & 4.27 & 10.35 & 10.40 & 30 & dolomite & no \\
\hline AFM-4D & 0.94 & 0.94 & 3.01 & 5.13 & 10.40 & 10.38 & 45 & dolomite & scarce \\
\hline AFM-5D & 1.5 & 1.5 & 4.43 & 6.99 & 10.49 & 10.43 & 95 & dolomite & clear \\
\hline AFM-6D & 1.57 & 1.57 & 4.59 & 7.19 & 10.49 & 10.49 & 100 & dolomite & clear \\
\hline AFM-1K & 0.57 & 0.57 & 1.89 & 3.62 & 10.30 & 10.24 & 20 & kutnahorite & no \\
\hline AFM-2K & 0.64 & 0.64 & 2.12 & 3.93 & 10.33 & & 25 & kutnahorite & clear \\
\hline AFM-3K & 0.72 & 0.72 & 2.46 & 4.23 & 10.35 & 10.40 & 30 & kutnahorite & clear \\
\hline AFM-4K & 1.00 & 1.00 & 3.17 & 5.35 & 10.41 & 10.53 & 50 & kutnahorite & clear \\
\hline
\end{tabular}

kutnahorite compared with that of dolomite, which is difficult to detect due to the similar scattering factors of $\mathrm{Mn}$ and $\mathrm{Ca}$ atoms.

Semiquantitative chemical analysis of the sample surfaces was conducted with a Link-analytical EDX detector installed on a JEOL JSM6400-40 kV scanning electron microscope (SEM). From the chemical analyses the following formulas were calculated: $\mathrm{Mg} 0.8{ }_{4} \mathrm{Ca}$ ${ }_{1.06} \mathrm{Fe} \quad 0.08 \mathrm{Mn} \quad 0.0 \quad 1 \quad\left(\mathrm{CO}_{3}\right)_{2}$ for dolo mite and $\mathrm{Mn}_{1.17} \mathrm{Ca}_{0.74} \mathrm{Mg}_{0.03} \mathrm{Zn}_{0.03} \mathrm{Fe}_{0.02}\left(\mathrm{CO}_{3}\right)_{2}$ for kutnahorite. These analyses show that dolomite sample contain a lower amount of impurities than the kutnahorite sample. This is consistent with the lower degree of ordering detected in kutnahorite by X-ray diffraction.

2.2. Crystallization Experiments. Two series of experiments were conducted by submerging dolomite or kutnahorite in super-saturated solutions with respect to calcite at room temperature. Large dolomite and kutnahorite samples were cleaved with a razor blade and a hammer to obtain rhombohedra with $\{104\}$ faces of about $20 \mathrm{~mm}^{2}$. The rhombohedra were placed in vessels containing $2 \mathrm{~mL}$ of static supersaturated solutions, which were closed with polypropylene caps to avoid evaporation and contact with the atmosphere. Solutions were prepared from reagent grade $\mathrm{CaCl}_{2}$ and $\mathrm{Na}_{2} \mathrm{CO}_{3}$ solutions and deionized water (Milli-Q; resistivity 18 $\mathrm{M} \Omega \mathrm{cm}$ ). Supersaturations of the solutions with respect to calcite were calculated using the following expression:

$$
\beta_{\text {calcite }}=\frac{a\left(\mathrm{Ca}^{2+}\right) \cdot a\left(\mathrm{CO}_{3}^{2-}\right)}{K_{\text {sp }, \text { calcite }}}
$$

where $\mathrm{a}\left(\mathrm{Ca}^{2+}\right)$ and $\mathrm{a}\left(\mathrm{CO}_{3}{ }^{2-}\right)$ are the activities of the ions in the solution and $\mathrm{K}_{\mathrm{sp}, \text { calcite }}=10^{-8.48}$ is the solubility product of calcite at $25^{\circ} \mathrm{C}$. Ionic activities and pHs were calculated using the PHREEQC computer code and the PHREEQC.DAT database. ${ }^{19}$ Independent measurements of the $\mathrm{pH}$ of the solutions were also carried out with a $\mathrm{pH}$-meter (PH5 Plus Complet Eutech Instruments). Table 1 shows the concentrations, the ionic activities, the pHs, and the initial supersaturations with respect to calcite of the aqueous solutions and substrates used in the crystallization experiments (columns 2 to 9 ). Dolomite and kutnahorite crystals were kept in the solutions for periods of time of about $24 \mathrm{~h}$. Then crystals were removed from the vessels, dried, and mounted on a sample holder to be imaged by SEM (JEOL JSM6400-40 kV).

2.3. In Situ AFM Growth Experiments. In situ nanoscale observations of epitaxial growth of calcite on dolomite and kutnahorite (104) faces were carried out at room temperature in an AFM (Nanoscope Illa Multimode, Veeco Instruments) equipped with a $\sim 15 \times 15 \mu \mathrm{m}^{2}$ scanner and a fluid cell. All the AFM images were recorded in constant force mode while displaying the cantilever height, vertical deflection, and lateral deflection (friction) signals. Scan areas varied from $5 \times 5 \mathrm{n} \mathrm{m}^{2}$ to $14 \times 14 \mu \mathrm{m}^{2}$. Tips supported by triangular cantilevers (Bruker SNL-10) and rectangular cantilevers (Bruker TESP and NT-MDT CSG01) were used. Scan rates varied from $\sim 5$ t $0 \sim 60$ $\mathrm{Hz}$, and 256 to 512 lines per scan were recorded. Dolomite and kutnahorite crystals were freshly cleaved along (104) faces with a razor blade immediately before being placed in the fluid cell of the AFM.
Then deionized water was passed over the surfaces to remove impurities on the surfaces and adjust AFM parameters. Growth on dolomite and kutnahorite (104) surfaces was promoted by injecting supersaturated aqueous solutions with respect to calcite in the AFM fluid cell. Solutions were prepared following the protocol described in section 2.2. As in the case of the crystallization experiments, supersaturations of the solutions with respect to calcite were calculated using eq 1 and the PHREEQC computer code. Table 2 shows the concentrations, ionic activities, $\mathrm{pH}$, the initial supersaturations with respect to calcite of the aqueous solutions, and substrates used in the AFM growth experiments (columns 2 to 9).

More than 2000 AFM images were collected and subsequently analyzed using the software provided by Nanoscope (5.30r3sr3) and Nanotec (WSxM). ${ }^{20}$

2.4. Nanomanipulation Experiments. Once epitaxial growth was observed, nanomanipulation experiments were performed to remove calcite islands from dolomite and kutnahorite (104) surfaces. To this end, the applied vertical force between the AFM tip and the surfaces was progressively increased till the islands were detached from the substrate. The lateral force signal simultaneously acquired with the topography made possible an estimation of the shear strength required to move the islands. This is simply given by the formula ${ }^{22} T=F_{L} / A$, where $F_{L}$ is the lateral force and $A$ is the area of contact, as estimated from topography images acquired prior to the manipulation events. The lateral forces were calibrated according to the formula ${ }^{21}$

$$
F_{\mathrm{L}}=\frac{3 h}{2 L} k_{\mathrm{T}} S \cdot V_{\mathrm{L}}
$$

where $k_{T}$ is the torsional spring constant of the cantilever, $h$ is the height of the tip (including half of the cantilever thickness), $L$ is the length of the cantilever, $S$ is the sensitivity of the photodetector in units of $n m / N$, and $V_{L}$ is half of the difference (in volts) between the trace and retrace signals. The torsional spring constant can be calculated using the relation

$$
k_{\mathrm{T}}=\frac{G w t^{3}}{3 h^{2} L}
$$

where $G$ is the shear modulus of the cantilever, and $w$ and $t$ are its width and thickness, respectively. Note that in this case rectangular cantilevers have been used since their calibration is easier than the calibration of V-shaped cantilevers.

\section{RESULTS}

3.1. Overgrowth of Calcite Crystals on Dolomite and Kutnahorite Crystals. After about $24 \mathrm{~h}$ of being immersed in supersaturated solutions with respect to calcite, dolomite and kutnahorite rhombohedra showed a different degree of coverage by calcite crystals. Typically, large calcite crystals appear on kutnahorite substrates for $\beta_{\text {calcite }}>20$ and on dolomite for $\beta_{\text {calcite }}>40$. For lower supersaturations than those, only small calcite crystals have been occasionally observed on 

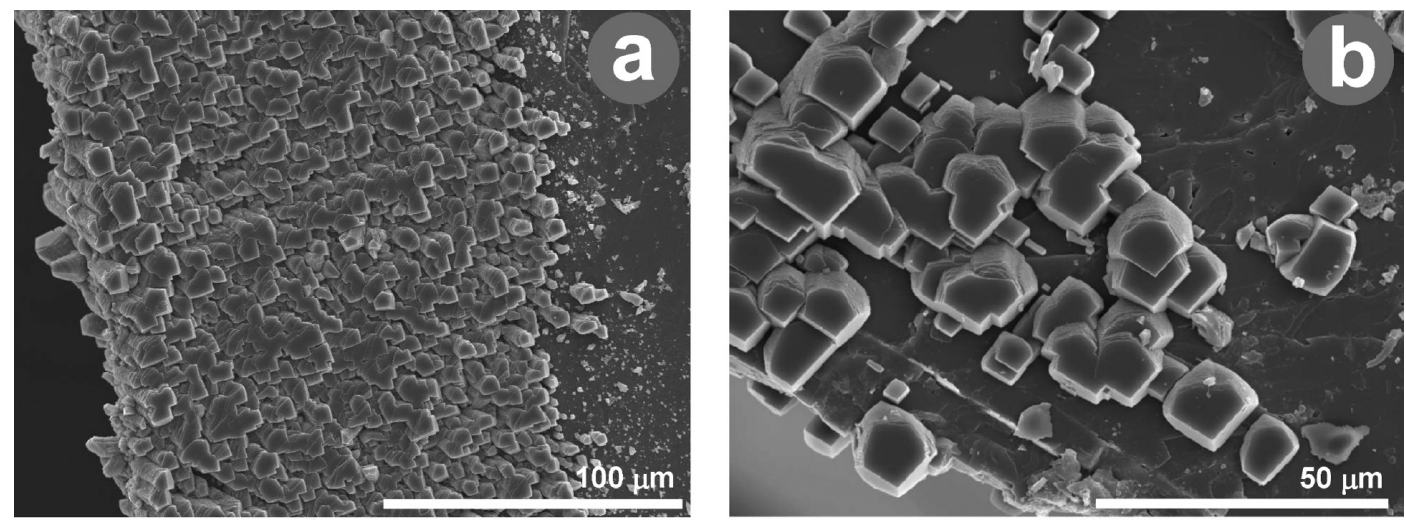

Figure 1. SEM images of epitaxial growth of calcite crystals on rhombohedral crystals of (a) dolomite (experiment C-6D in Table 1) and (b) kutnahorite (experiment C-6K in Table 1).
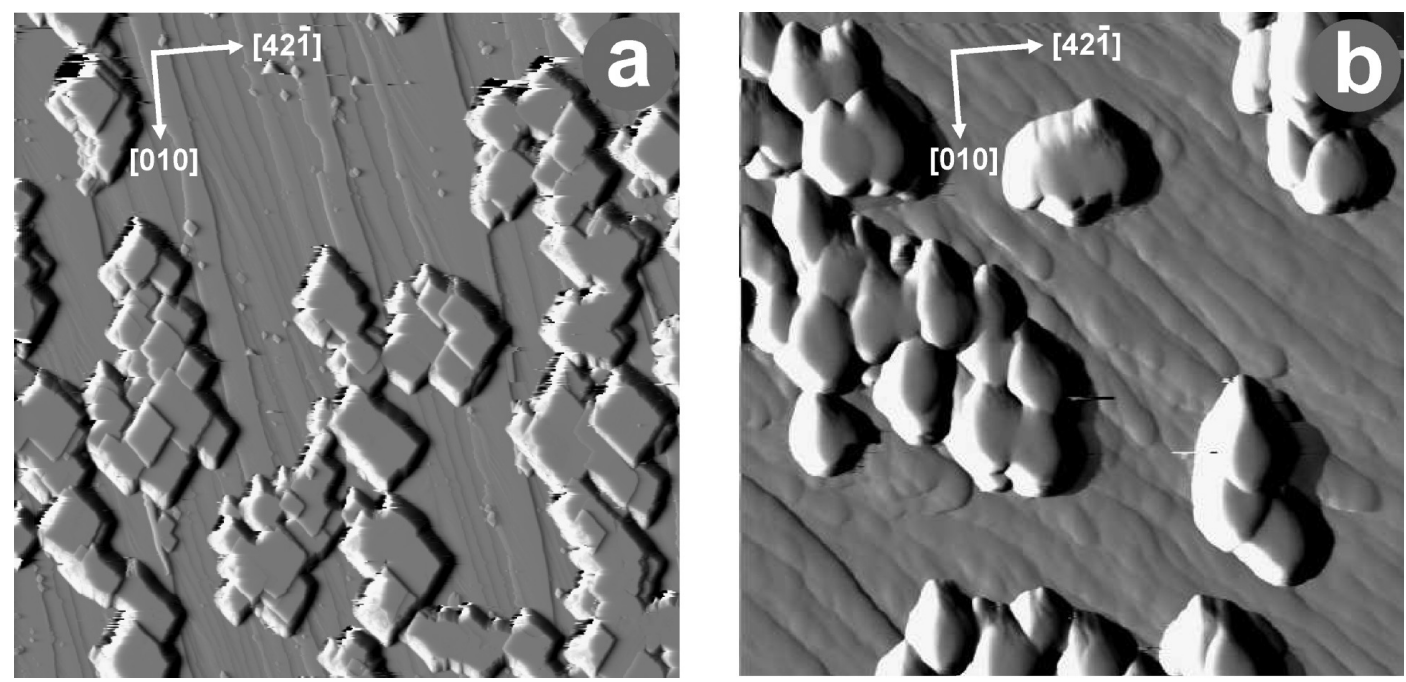

Figure 2. AFM deflection images of calcite islands growing epitaxially on (104) surfaces of (a) dolomite (experiment AFM-6D in Table 2; scan area: $14 \times 14 \mu \mathrm{m}^{2}$ ) and (b) kutnahorite (experiment AFM-4K in Table 2; scan area: $5 \times 5 \mu \mathrm{m}^{2}$ ). In this image a slight convolution between the AFM tip and the surface occurred. Main crystallographic directions are indicated by white arrows.

kutnahorite and dolomite surfaces. Calcite crystals grown on both kutnahorite and dolomite rhombohedra have a rhombohedral morphology which often shows a rounded corner. The existence of a rounded corner in the overgrown calcite crystals is more evident when they form on kutnahorite rather than on dolomite, revealing differences in the lateral growth of the crystals. In addition, calcite crystals are highly oriented with respect to the substrates, i.e., the growth is epitaxial. However, as can be seen in Figure 1, both epitaxies do not proceed by a homogeneous layer-by-layer growth but by the formation of large three-dimensional islands that eventually coalesce and cover the substrates. These islands are initially almost perfect $\{104\}$ rhombohedra which become progressively elongated perpendicular to the (104) plane that lies parallel to the substrates. This indicates that, on both substrates, the lateral growth of calcite is less favorable than the vertical growth. As a result of such an epitaxial growth, dolomite and kutnahorite (104) substrates become covered by a columnar arrangement of calcite crystals.

3.2. Nanoscale Observations of Epitaxial Growth of Calcite on Dolomite and Kutnahorite (104) Faces. A few seconds after injecting highly supersaturated solutions with respect to calcite in the fluid cell of the AFM, the nucleation of calcite islands on both dolomite and kutnahorite (104) surfaces is observed. As in the case of the experiments described in section 3.1, supersaturation levels required to clearly observe calcite islands growing on dolomite (104) are higher than on kutnahorite (104). In addition, the scan rate and the AFM cantilevers used influence the nucleation process. The higher the scan velocities and the stiffer the cantilever, the lower the nucleation density. This has been checked several times by imaging different areas of the substrates some minutes after the first injection of growth solution. However, once islands attach to the substrate and become larger, their removal during scan is a rare event. As will be explained in section 3.3, only when the AFM tip loading force is increased, calcite islands can be removed from the substrates. Figure 2 shows calcite islands growing on dolomite and kutnahorite (001) surfaces. In both cases, calcite islands are oriented with their (104) planes parallel to the substrates (104) faces and with the [421] and [010] crystallographic directions also parallel. The parallelism between the [421] and [010] directions has been also confirmed by high resolution AFM images (Supporting Information, Figure S1). In these images, the coincidence of the substrate and overgrowths lattices has been observed.

A few minutes after starting the growth experiments, the growth of calcite on dolomite and kutnahorite (104) faces is faster perpendicularly to the surfaces than over the surfaces. As 
a result, large three-dimensional clusters of calcite islands are observed on both surfaces. Interestingly, when their thickness is higher than a few hundreds of nanometers, numerous growth spirals are often observed on the surfaces of the calcite clusters formed on dolomite (Figure 3). These spirals have a polygonal shape similar to that previously observed on pure calcite (104) surfaces. $^{23}$
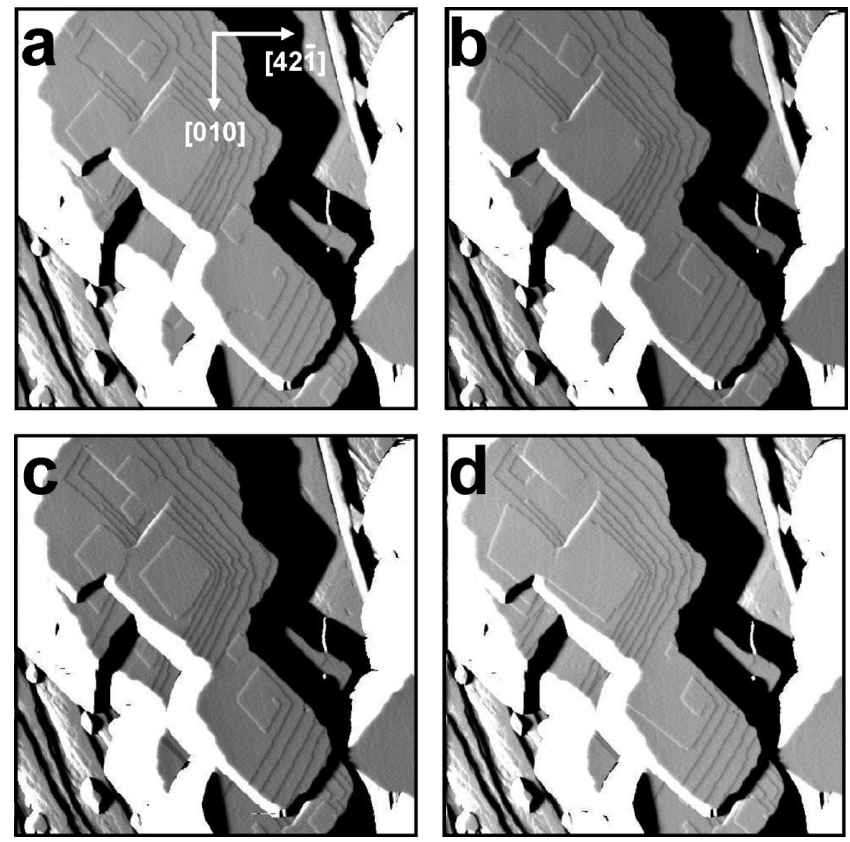

Figure 3. Sequence of AFM deflection images showing growth spirals on calcite crystals formed on dolomite (104) surface (experiment AFM-6D; scan area: $\left.2 \times 2 \mu \mathrm{m}^{2}\right)$. Main crystallographic directions are indicated by white arrows in panel a.

3.3. Nanomanipulation of Calcite Islands Grown on Dolomite and Kutnahorite Surfaces. Figure 4 shows the detachment of a calcite island and an aggregate of two calcite islands from a dolomite (104) surface. The lateral friction force peaks up when the nanomanipulation events occur, and suddenly goes back to values corresponding to the bare dolomite substrate. In the next scan lines, the islands disappear in both topography and friction signal, so that they look truncated in complete images. This indicates that the islands have been suddenly removed from the surface. Whether they "exploded" or were lost in the solution without losing their integrity, it is not possible to determine from these images alone. None of the islands could be found again, after zooming out and acquiring topography images on larger areas including the region in Figure 4. Since the contact area of the removed islands can be estimated from topography images acquired before the nanomanipulation events, the shear strength can be easily determined from the peak value of the lateral force. $^{22}$ By neglecting differences in the roughness of the substrates due to differences in step density, we found that calcite islands were usually removed from dolomite (104) surfaces with low density of steps for shear strengths $\mathrm{T} \approx 7 \mathrm{MPa}$. In the case of calcite islands on kutnahorite (104) surfaces, we estimated in a similar way a much larger shear strength $\mathrm{T} \approx 130 \mathrm{MPa}$.
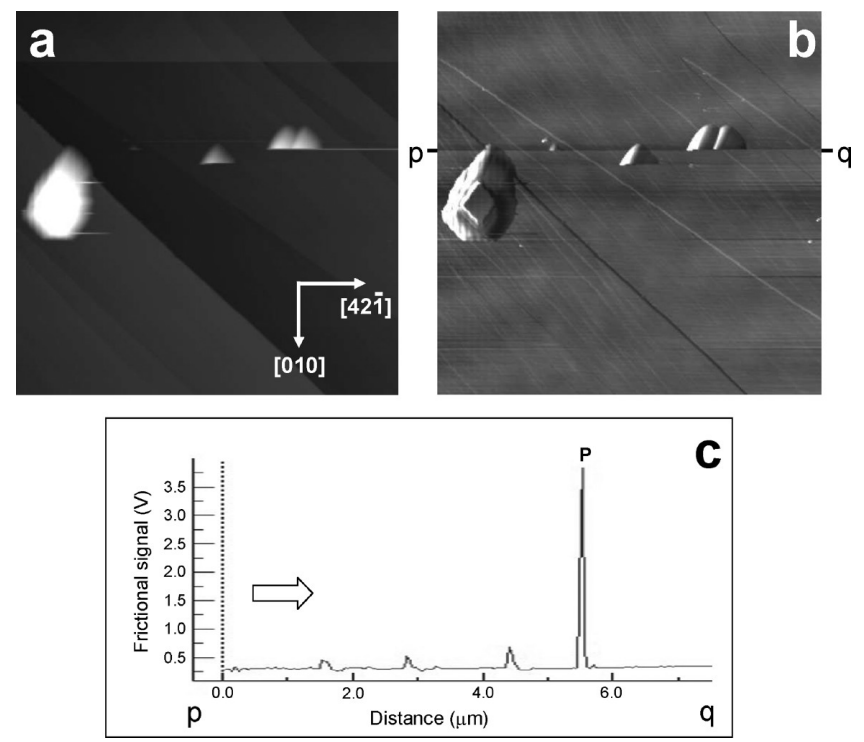

Figure 4. Detachment of calcite islands previously grown on a dolomite (104) face. (a) Height AFM image. (b) Friction AFM image (trace). Both images are $7.5 \times 7.5 \mu \mathrm{m}^{2}$ in size. Main crystallographic directions are indicated by white arrows in panel a. (c) Profile of the frictional signal taken along the line $p-q$ in panel $b$. The main detachment event occurred at the highest frictional peak $(P)$. The arrow indicates the scan direction. From frictional profiles like that shown in panel $\mathrm{C}$, shear strength for detachment of both individual calcite islands and clusters can be determined.

\section{DISCUSSION}

Both SEM images and AFM observations of the epitaxial growth of calcite on dolomite and kutnahorite (104) surfaces are consistent with the so-called Volmer-Weber growth mode. According to this epitaxial mode, the formation of three-dimensional islands is energetically more favorable than a homogeneous layer-by-layer coverage of the substrate. This usually occurs when the lattice misfits between crystallographic directions on the epitaxial plane are relatively high and, therefore, the lateral spreading of the epitaxial layers is strongly reduced. Misfits between calcite and kutnahorite and dolomite structures on the common epitaxial (104) plane can be calculated by the following expression:

$$
\delta_{[u v w]}^{104}=\frac{L_{\mathrm{dol} / \mathrm{kut}}-L_{\mathrm{cal}}}{L_{\mathrm{cal}}} \times 100
$$

where $L_{\text {dol/kut }}$ and $L_{\text {cal }}$ are the repeat periods along the dolomite (or kutnahorite) and calcite common directions, respectively. Considering the parameters of the surface rectangular lattice defined by the [421] and [010] directions (see Table 3), the calculated misfits using eq 4 are $\delta^{104}{ }_{[421]}=-4.79 \%$ and $\delta^{104}[010]=$ $-3.59 \%$ for calcite on dolomite, and $\delta_{[42 \overline{1}]}^{104}=-3.17 \%$ and $\delta_{[010]}^{104}$ $=-2.21 \%$ for calcite on kutnahorite. Although these misfits are much lower than $15 \%$ (i.e., the misfit above which it is

Table 3. Parameters of the Rectangular Surface Cell on the Calcite, Dolomite, and Kutnahorite (104) Faces

\begin{tabular}{lcc}
\multicolumn{1}{c}{ mineral } & {$[010](\mathrm{nm})$} & {$[42 \overline{1}](\mathrm{nm})$} \\
calcite $^{29}$ & 0.499 & 0.810 \\
dolomite $^{30}$ & 0.481 & 0.771 \\
kutnahorite $^{31}$ & 0.488 & 0.784
\end{tabular}


considered that epitaxial growth cannot $\operatorname{occur}^{24}$ ), they are high enough for promoting Volmer-Weber epitaxial growth. This is in agreement with previous AFM investigations on epitaxies involving sulfates with the barite $\left(\mathrm{BaSO}_{4}\right)$ structure. ${ }^{25-27}$ Interestingly, these investigations have shown that, when absolute lattice misfits are higher than $\sim 4.8 \%$ in at least one crystallographic direction contained in the epitaxial plane, the Volmer-Weber mode is observed. This is the case of the epitaxial growth of celestite $\left(\mathrm{SrSO}_{4}\right)$ and anglesite $\left(\mathrm{PbSO}_{4}\right)$ on barite $(001)$ faces. ${ }^{25,26}$ Differently, the Stranski-Krastanov epitaxial mode, characteristic of moderate lattice misfits, has been reported for the growth of hashemite $\left(\mathrm{BaCrO}_{4}\right)$ on barite (001) faces, where the maximum lattice misfit is only $\sim 2.6 \%{ }^{28}$ When misfits are even lower, continuous layer-by-layer growth is expected, i.e., the Frank-Van der Merwe epitaxial growth becomes possible. This epitaxial mode has been observed for the epitaxy of anglesite on celestite (001) faces, which is consistent with a maximum misfit of $\sim 1.1 \%{ }^{27}$ Considering that barite-type sulfates and trigonal carbonates have similar crystallochemical schemes, it is not surprising that similar maximum misfits lead to the same epitaxial growth mode in both families of compounds, i.e., the Volmer-Weber mechanism.

The high misfits between the calcite and dolomite and kutnahorite lattices imply the existence of energy barriers for surface nucleation, which are related to lattice strain energies. Such energy barriers can be overcome by increasing the supersaturation of the growth solutions with respect to calcite. ${ }^{10}$ Our growth experiments show that critical super-saturations with respect to calcite are required to initiate Volmer-Weber epitaxial growth on both dolomite and kutnahorite (104) surfaces. Moreover, the critical super-saturation is higher when the substrate is dolomite

$\left(\beta_{\mathrm{calcite} / \text { dolomite }}^{\mathrm{VW}} \approx 40\right)$ than when the substrate is kutnahorite $\left(\beta_{\text {calcite/kutnahorite }}^{\mathrm{VW}} \approx 20\right)$. This difference in critical supersaturation for Volmer-Weber growth can be partially due to the higher misfits between calcite and dolomite lattices compared with the misfits between calcite and kutnahorite lattices. Nevertheless, the size of calcite nuclei formed on the substrates does not seem to strongly depend on misfits but on the supersaturation with respect to calcite. Thus, regardless of the substrate, higher supersaturations lead to the formation of smaller calcite islands, which is in agreement with the classical nucleation theory ${ }^{32}$ (Figures 1 and 2). In contrast, after the nucleation of calcite islands on both dolomite and kutnahorite substrates, crystal growth results in the formation of epitaxial overgrowths which are usually thicker on kutnahorite than on dolomite for similar supersaturations with respect to calcite. This indicates that epitaxial growth is strongly controlled by the overgrowth-substrate misfits.

As the Volmer-Weber epitaxial growth proceeds, the strain associated with the high lattice misfits needs to be somehow accommodated. At the initial stages of growth, lattice strain can be elastically accommodated in the first epitaxial layers. However, as the thickness of the three-dimensional islands increases, the accumulation of elastic deformation in the growth layers is not possible any more. As a result, above a critical thickness of the epitaxial overgrowths, the generation of dislocations occurs, i.e., misfit dislocations. The generation of screw dislocations on calcite overgrowths on dolomite has been detected by the observation of numerous growth spirals when those overgrowths reach a thickness of several hundreds of nanometers (see Figure 3). Although we have not observed growth spirals on calcite crystals on kutnahorite, the formation of screw dislocations is also expected to occur. However, due to the lower calcite/kutnahorite misfits, screw dislocations are probably generated for thicker calcite overgrowths. Since calcite/dolomite and calcite/kutnahorite misfits are all negative, the formation of screw dislocations on calcite overgrowths can be considered as a response to compressive stress. Sethmann et al. ${ }^{14}$ have also reported the formation of growth spirals on layers of Mg-calcite deposited on pure calcite (104) faces. In this case, however, such spirals respond to a tensile stress which generates a nanotopography consisting of a mosaic-like structure. These authors interpret the formation of such a surface structure as the result of a Stranski-Krastanov-like growth mode. The comparison of our AFM observations on dolomite (104) with those of Sethmann et al. ${ }^{14}$ on calcite (104) indicates that the epitaxial growth modes not only depend on the absolute misfit values between overgrowth and substrate but also on the sign of the associated stress (i.e., compressive or tensile).

Our nanomanipulation experiments demonstrate that calcite islands under compressive stress can be easily detached from the dolomite (104) surfaces and, with more effort, from the kutnahorite (104) surfaces. The shear strength estimated for detaching calcite from dolomite (104) is indeed $\sim 7 \mathrm{MPa}$, whereas it is almost 20 times larger on kutnahorite (104). The main reason for this significant difference can be attributed to the different lattice mismatches between calcite and the two substrates, i.e., $\delta-3.17 \%$ on kutnahorite and $-4.79 \%$ on dolomite (along the [421] direction). Since the interface between calcite and dolomite is much more stressed, detachment should occur more easily than in the case of calcite islands on kutnahorite. It is also worth noting that, after detachment, the island was lost in the liquid solution. This is quite different from what is observed in similar experiments in ultrahigh vacuum, where the detached islands are usually pushed by the probing tip and remain on the substrate. ${ }^{22,33}$

\section{CONCLUSIONS AND OUTLOOK}

The study presented here demonstrates that the epitaxial growth of calcite on dolomite and kutnahorite (104) only occurs at room temperature from aqueous solutions highly supersaturated with respect to calcite. Our results show that the growth is mainly controlled by the misfits between the overgrowth and substrate surface lattices. The relatively high lattice misfits (higher than $2.2 \%$ ) determine a Volmer-Weber epitaxial growth mode, in agreement with previous AFM investigations on epitaxial growth on the surfaces of trigonal carbonates ${ }^{5,10,14}$ and sulfates with the barite structure. ${ }^{25-28}$ Moreover, our experiments show that the minimum super-saturation required to promote calcite epitaxial growth increases with the lattice misfit (i.e., it is higher for the dolomite (104) substrate). Finally, nanomanipulation experi-ments allowed us to estimate the shear strengths required to remove calcite islands from the dolomite and kutnahorite substrates. The shear strength was found to decrease when the lattice misfit increases, confirming that the difference between the crystallographic parameters between overgrowth and substrate is an important controlling parameter of the epitaxial growth of calcite on dolomite and kutnahorite (104) faces. Although systematic measurements are still required for a better quantification of this effect, the nanomanipulation method presented in this paper has been revealed as a new interesting tool to quantify epitaxial growth phenomena 
occurring on mineral surfaces in aqueous environments. Future growth and nanomanipulation experiments conducted on surfaces with the dolomite structure as those presented here will further contribute to a better understanding of the complex reactivity of this group of minerals.

Supporting Information

Combination of AFM images showing the parallel orientation of the crystal lattices of the overgrown calcites and the dolomite (104) substrate. This material is available free of charge via the Internet at http://pubs.acs.org.

\section{AUTHOR INFORMATION}

Corresponding Author

*E-mail: cmpina@geo.ucm.es.

Notes

The authors declare no competing financial interest.

\section{ACKNOWLEDGMENTS}

This work was supported by the Spanish Government (Projects MAT2011-26312 and MAT2012-24487). AFM and SEM observations were carried out at ICTS Centro Nacional de Microscopia Electrónica, Madrid. X-ray diffraction measure-ments were conducted at the Centro de Difracción (UCM). The authors are very grateful to Prof. Alfonso Mucci for kindly providing the kutnahorite sample used in this work. We thank three anonymous reviewers for insightful comments on the article.

\section{REFERENCES}

(1) Deelman, J. C. Neues Jahrb. Mineral. 1999, 7, 289-302.

(2) Deelman, J. C. Low-Temperature formation of dolomite and magnesite, version 2.3; 2011.

(3) Lippmann, F. Sedimentary Carbonate Minerals; Springer-Verlag: 1973.

(4) Sherman, L. A.; Barak, P. Soil Sci. Soc. Am. J. 2000, 64, 1959-

1968.

(5) Hu, X.; Grossie, D. A.; Higgins, S. R. Am. Mineral. 2005, 90, 963

-968 .

(6) Mucci, A. Aquat. Geochem. 2004, 10, 139-169.

(7) Katsikopoulos, D.; Fernández-González, A.; Prieto, M. Geochim. Cosmochim. Acta 2009, 73, 6147-6161.

(8) Tareen, J. A. K.; Fazeli, A. R.; Basavalingu, B.; Bhandige, G. T. J. Therm. Anal. 1995, 44, 937-954.

(9) Higgins, S. R.; Hu, X. Geochim. Cosmochim. Acta 2005, 69, 20852094.

(10) Frank, F. C.; Van Der Merwe, J. Proc. R. Soc. A 1949, 198, 216. (11) Astilleros, J. M.; Pina, C. M.; Fernández-Díaz, L.; Putnis, A. Berichte der Deutschen Mineralogischen Gesellschaft. Eur. J. Mineral. 2003, 15 (1), 8.

(12) Davis, K. J.; Dove, P. M.; DeYoreo, J. J. Science 2000, 290, $1134-1137$.

(13) Davis, K. J.; Dove, P. M.; Wasylenki, L. E.; De Yoreo, J. J. Am. Mineral. 2004, 89, 714-720.

(14) Sethmann, I.; Wang, J.; Becker, U.; Putnis, A. Cryst. Growth Des. 2010, 10, 4319-4326.

(15) Stranski, I. N.; Krastanov, V. L. Akademie der Wissenschaften und Literatur Mainz, Mathematisch-Naturwissenschaftliche Klasse Ilb 1939, 146, 797.

(16) Astilleros, J. M.; Pina, C. M.; Fernández-Díaz, L.; Putnis, A. Geochim. Cosmochim. Acta 2002, 66, 3177-3189.

(17) Lea, A. S.; Hurt, T. T.; El-Azab, A.; Amonette, J. E.; Baer, D. R. Surf. Sci. 2003, 524, $63-77$.

(18) Volmer, M.; Weber, A. Z. Phys. Chem. 1926, 119, 277.
(19) Parkhurst, D. L.; Appelo, C. A. J. User's guide to PHREEQC (version 2) - a computer program for speciation, reaction-path, 1D-transport, and inverse geochemical calculations; U.S. Geological Survey; Water-Resources Investigations Report 2000.

(20) Horcas, I.; Fernández, R.; Gómez-Rodríguez, J. M.; Colchero, J.; Gómez-Herrero, J.; Baró, A. M . Rev. Sci. Instrum. 2007, 78, 013705-1 $-8$.

(21) Lüthi, R.; Meyer, E.; Haefke, H.; Howald, L.; Gutmannsbauer, W.; Guggisberg, M.; Bammerlin, M.; Güntherodt, H. J. Surf. Sci. 1995, 338, 247-260.

(22) Lüthi, R.; Meyer, E.; Haefke, H.; Howald, L.; Gutmannsbauer, W.; Güntherodt, H. J. Science 1994, 266, 1979-1981.

(23) Teng, H. H.; Dove, P. M.; DeYoreo, J. J. Geochim. Cosmochim. Acta 2000, 64, 2255-2266.

(24) Herman, M. A.; Richter, W.; Sitter, H. Epitaxy: Physical Foundation and Technical Implementation; Springer, 2004.

(25) Sánchez-Pastor, N.; Pina, C. M.; Astilleros, J. M.; Fernández-Díaz, L.; Putnis, A. Surf. Sci. 2005, 581, 225-235.

(26) Pina, C. M.; Rico-García, A. Macla 2008, 9, 191-192.

(27) Pina, C. M.; Rico-García, A. Surf. Sci. 2009, 603, 2708-2713.(28)

Shtukenberg, A. G.; Astilleros, J. M.; Putnis, A. Surf. Sci. 2005, 590, 212-223.

(29) Rode, S.; Oyabu, N.; Kobayashi, K.; Yamada, H.; Kühnle, A. Langmuir 2009, 25, 2850-2853.

(30) Miser, D. E.; Swinnea, J. S.; Steinfink, H. Am. Mineral. 1987, 72, 188-193.

(31) Graf, D. L. Am. Mineral. 1961, 46, 1283-1316.

(32) Walton, A. G. Nucleation in liquids and solutions. In Nucleation; Zettlemoyer, Ed.; Marcel Dekker Inc.: New York, 1969.

(33) Dietzel, D.; Ritter, C.; Mönninghoff, T.; Fuchs, H.; Schirmeisen, A.; Schwarz, U. D. Phys. Rev. Lett. 2008, 101, 125505. 